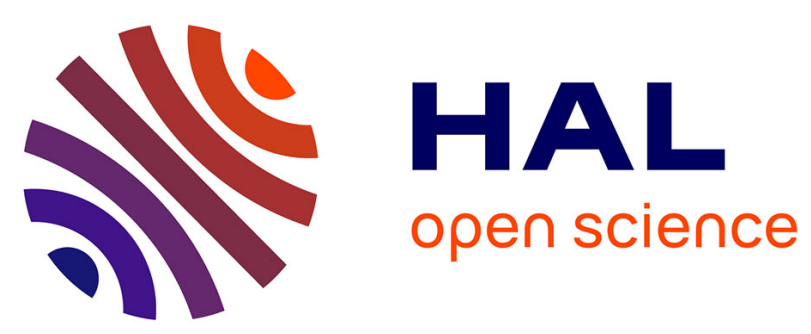

\title{
Evidence that the marine-derived multi-mineral Aquamin has anti-inflammatory effects on cortical glial-enriched cultures.
}

Sinead Ryan, Denise O'Gorman, Yvonne Nolan

\section{To cite this version:}

Sinead Ryan, Denise O'Gorman, Yvonne Nolan. Evidence that the marine-derived multi-mineral Aquamin has anti-inflammatory effects on cortical glial-enriched cultures.. Phytotherapy Research, 2010, 10.1002/ptr.3309 . hal-00599843

\section{HAL Id: hal-00599843 \\ https://hal.science/hal-00599843}

Submitted on 11 Jun 2011

HAL is a multi-disciplinary open access archive for the deposit and dissemination of scientific research documents, whether they are published or not. The documents may come from teaching and research institutions in France or abroad, or from public or private research centers.
L'archive ouverte pluridisciplinaire HAL, est destinée au dépôt et à la diffusion de documents scientifiques de niveau recherche, publiés ou non, émanant des établissements d'enseignement et de recherche français ou étrangers, des laboratoires publics ou privés. 


\section{Evidence that the marine-derived multi-mineral Aquamin has anti-inflammatory effects on cortical glial-enriched cultures.}

\begin{tabular}{|r|l|}
\hline Journal: & Phytotherapy Research \\
\hline Manuscript ID: & PTR-10-0614.R1 \\
\hline Wiley - Manuscript type: & Short Communication \\
\hline $\begin{array}{r}\text { Date Submitted by the } \\
\text { Author: }\end{array}$ & 18 -Aug-2010 \\
\hline Complete List of Authors: & $\begin{array}{l}\text { Ryan, Sinead; University College Cork, Anatomy and Neuroscience } \\
\text { O'Gorman, Denis; Marigot Limited } \\
\text { Nolan, Yvonne; University College Cork, Anatomy and Neuroscience }\end{array}$ \\
\hline Keyword: & inflammation, Aquamin, IL-1beta, TNFalpha, glia, brain \\
\hline \multicolumn{2}{|r}{} \\
\hline
\end{tabular}

\section{SCHOLARONE" Manuscripts}


Evidence that the marine-derived multi-mineral Aquamin has anti-inflammatory effects on cortical glial-enriched cultures.

\author{
Sinead Ryan ${ }^{1}$, Denise M. O’Gorman ${ }^{2}$, Yvonne M. Nolan ${ }^{1 *}$ \\ ${ }^{1}$ Department of Anatomy and Neuroscience, University College Cork, Ireland \\ ${ }^{2}$ Marigot Limited, Strand Farm, Currabinny, Carrigaline, Co Cork, Ireland
}

*Corresponding author: Yvonne M. Nolan, Department of Anatomy and Neuroscience, University College Cork, Ireland

Tel: 353 (0)21 4902787, Fax: 353214273518 email: y.nolan@ucc.ie

Short Title: Anti-inflammatory properties of Aquamin in cortical glia

Key words: Inflammation; Aquamin, glia, TNF $\alpha$, IL-1 $\beta$, brain

This work was funded by Marigot Ltd. There are no conflicts of interest. 


\begin{abstract}
It is well established that neuroinflammation contributes to brain aging, and that cortical cells are particularly vulnerable. Lipopolysaccharide stimulates the release of the proinflammatory cytokines, tumor necrosis factor-alpha and interleukin-1beta from glial cells which consequently induces an impairment in neuronal cell function. The food supplement Aquamin is a natural, multi-mineral derived from the red algae Lithothamnion corallioides, rich in calcium, magnesium and 72 other trace minerals. The aim of this study was to evaluate the anti-inflammatory potential of Aquamin in lipopolysaccharide-stimulated, glial-enriched primary cultures of rat cortex. We report that Aquamin prevented lipopolysaccharide-induced secretion of tumor necrosis factoralpha and interleukin-1beta from cortical glia. These data suggest that nutritional supplements such as Aquamin may play an important role in impeding the detrimental effects of excessive inflammation in the brain.
\end{abstract}

\title{
Introduction
}

Minerals such as magnesium copper, zinc, manganese and selenium are now recognized as important regulators of inflammation and growing evidence suggests that mineralrich seaweed extracts may play an important role in the regulation of inflammation (Granert et al., 1999; Jung et al., 2007). The food supplement, Aquamin is a natural seaweed-derived multi-mineral from the red algae Lithothamnion corallioides which is rich in calcium, magnesium and trace amounts of other minerals (Table 1). It has recently been shown to provide relief from the symptoms of osteoarthritis (Frestedt et 
$a l ., 2009$ ) and to be of benefit in digestive and bone health (Aslam et al., 2010a; Aslam et al., 2010b).

It is well established that inflammation contributes to cortical neuronal dysfunction in age-related neurological diseases such as Alzheimer's disease, amyotrophic lateral sclerosis, multiple sclerosis and Parkinson's disease (Minghetti, 2005). Microglia are considered the resident immune cells of the brain and along with astrocytes, constitute the major glial cell types. Under conditions such as neurodegenerative disease, injury, exposure to environmental toxins, infection or age, microglia become activated to release large numbers of mediators such as cytokines and free radicals. Microglialsecreted pro-inflammatory cytokines such as interleukin-1 beta (IL-1 $\beta$ ) and tumor necrosis factor alpha $(\mathrm{TNF} \alpha)$ can influence neurons and their ability to process information and can ultimately contribute to neuronal cell death. Astrocytes provide structural and metabolic support to neurons and also play a role in brain inflammation through antigen presentation and cytokine secretion. It has previously been reported that exposure to the endotoxin lipopolysaccharide (LPS) induces release of IL-1 $\beta$ and TNF $\alpha$ from cortical glia to contribute to neuronal degeneration (Long-Smith et al., 2010). The present study was designed to investigate the anti-inflammatory potential of Aquamin in LPS-stimulated, glial-enriched rat cortical cultures to determine if nutritional supplements, such as Aquamin, may play a role in impeding the detrimental effects of excessive inflammation in the brain.

\section{Materials and Methods}


Aquamin (Food and Drug Administration (FDA) GRAS 000028) was prepared from the mineral-rich red marine algae, Lithothamnion corallioides harvested off the Atlantic coasts of Ireland and Iceland under approved licenses. The calcified seaweed was separated from extraneous materials, sterilized, dried and milled under ISO and HACCP certification. Approximately $0.5 \mathrm{mg} / \mathrm{ml}$ of Aquamin is equivalent to a physiological level of extracellular $\mathrm{Ca}^{2+}$. The concentrations of Aquamin were determined from previous experiments using low passage human dermal fibroblasts, calcium sensitive and calcium resistant colon carcinoma cell lines (CBS, Moser, Fet, HCT-116 and SW480) (Aslam et al., 2009), the murine macrophage cell line RAW 264.7, and the preosteoblastic cell line MC3T3-E1 (unpublished data). Aquamin demonstrated no signs of toxicity at any of the concentrations used in the current study. Glial-enriched cultures were prepared from cortical tissue isolated from seven separate postnatal day 2 SpragueDawley rat pups (Biological Services Unit, University College Cork) as previously described (Long-Smith et al., 2010). All scientific procedures were performed under a license issued by the Department of Health and Children (Ireland) and in accordance with the European Communities Council Directive (86/609/EEC). After 7-10 days in vitro (DIV), glia were incubated in the presence or absence of LPS $(50 \mathrm{ng} / \mathrm{ml})$ and Aquamin $(0.05,0.1,0.5,1$ and $2 \mathrm{mg} / \mathrm{ml})$. Twenty-four hours later, supernatant was removed for analysis of TNF $\alpha$ and IL-1 $\beta$ by ELISA (R\&D Systems, UK). Untreated culture media was used as a control. The cells were assessed for morphological signs of apoptosis and necrosis (loss of cell membrane asymmetry and attachment, cell shrinkage, cell blebbing, nuclear fragmentation and chromatin condensation) prior to, during and after 24 hours incubation with Aquamin. All cells were considered viable throughout the experiment. ANOVA with post hoc Student Newman-Keuls was used to 
determine which conditions were significantly different from each other. Results were expressed as means with standard error of the mean (SEM) and deemed significant when $\mathrm{p}<0.05$.

\section{Results and Discussion}

The data presented demonstrate that LPS induced a significant increase in TNF $\alpha$ (Figure 1A) and IL-1 $\beta$ (Figure 1B) secretion from glial-enriched cortical cultures 24 hours after LPS treatment $(\mathrm{p}<0.001)$. Treatment with all doses of Aquamin significantly attenuated the LPS-induced increase in TNF $\alpha$ and IL- $1 \beta$ secretion $(\mathrm{p}<0.01)$. Analysis of extracellular concentrations of TNF $\alpha$ revealed that Aquamin prevented its release from LPS-stimulated cortical glial cells in a dose-dependent manner and that all doses of Aquamin significantly attenuated the LPS-induced release of IL-1 $\beta$. These data suggest that the anti-inflammatory effects of Aquamin may be reliant on blockade of the proinflammatory effects of both TNF $\alpha$ and IL-1 $\beta$.

Seaweed extracts have previously been reported to inhibit pro-inflammatory cytokine release. Fucoidans from brown algae have been shown to inhibit TNF- $\alpha$ and IL-1 production in cerebrospinal fluid in a rabbit meningitis model (Granert et al., 1999) and an extract from the seaweed Hizikia fusiform reduced TNF $\alpha$ production in LPSstimulated murine microglial cells (Jung et al., 2007). Aquamin is a seaweed-derived multi-mineral rich in calcium and magnesium. It has been shown that IL- $1 \beta$ reduced $\mathrm{Ca} 2+$ channel activity and influx in rat cortical neurons (MacManus et al., 2000) suggesting that $\mathrm{Ca} 2+$ supplementation may be beneficial in situations of excessive IL- 
$1 \beta$ concentration in the brain such as occurs with aging. Increased magnesium in the diet may influence inflammation through reducing the serum level of the proinflammatory C-reactive protein. Copper, zinc and manganese are essential cofactors of the antioxidant enzyme superoxide dismutase and selenium is a vital constituent of the antioxidant glutathione peroxidase. A compromised antioxidant defense has been observed in the cortex of aged rats in parallel with increased IL-1 $\beta$ concentration (McGahon et al., 1999). Accumulation of reactive oxygen species in the rat cortex and hippocampus has been demonstrated after LPS treatment (Nolan et al., 2003) while an antioxidant-enriched diet has been shown to reverse age-related and inflammatoryinduced neuronal deficits (McGahon et al., 1999). Consequently, many of the antioxidant-related minerals that compose Aquamin may be anti-inflammatory and may directly or indirectly have neuroprotective properties.

The current study provides clear evidence that Aquamin exerts anti-inflammatory effects by preventing LPS-induced TNF $\alpha$ and IL-1 $\beta$ release from rat cortical glia. This evidence for an anti-neuroinflammatory activity of the food supplement Aquamin may have significant implications for brain health 


\section{References}

Aslam MN, Bhagavathula N, Paruchuri T, Hu X, Chakrabarty S, Varani J. 2009.

Growth-inhibitory effects of a mineralised extract from the red marine algae,

Lithothamnion calcareum, on $\mathrm{Ca} 2+$,-sensitive and $\mathrm{Ca} 2+-$-resistant human colon

carcinoma cells. Cancer Letts 283: 186-192.

Aslam MN, Kreider JM, Paruchuri T, Bhagavathula N, DaSilva M, Zernicke RF, Goldstein SA, Varani J. 2010. A mineral-rich extract from the red marine algae Lithothamnion calcareum preserves bone structure and function in female mice on a Western-style diet. Calcif Tissue Intl 86: 313-324.

Aslam MN, Paruchuri T, Bhagavathula N, Varani J. 2010. A mineral-rich red algae extract inhibits polyp formation and inflammation in the gastrointestinal tract of mice on a high-fat diet. Integrat Cancer Ther 9: 93-99.

Frestedt JL, Kuskowski MA, Zenk JL. 2009. A natural seaweed derived mineral supplement (Aquamin F) for knee osteoarthritis: a randomised, placebo controlled pilot study Nutr J 8:7-14.

Granert C, Raud J, Waage A, Lindquist L. 1999. Effects of polysaccharide fucoidin on cerebrospinal fluid interleukin-1 and tumor necrosis factor alpha in pneumococcal meningitis in the rabbit. Infect Immun 67:2071-2074. 
Jung K, Ha E, Uhm Y, Park H, Kim MJ, Kim H, Baik H, Hong M, Yang J, Yim SV. 2007. Suppressive effect by Hizikia fusiforme on the production of tumor necrosis factor in BV2 murine microglial cells. Neurol Res 29 Suppl 1:S88-92.

Long-Smith CM, Collins L, Toulouse A, Sullivan AM, Nolan YM. 2010. Interleukin-1 $\beta$ contributes to dopaminergic neuronal death induced by lipopolysaccharide-stimulated rat glia in vitro. J Neuroimmunol In Press.

MacManus A, Ramsden M, Murray M, Henderson Z, Pearson HA, Campbell VA. 2000. Enhancement of (45)Ca(2+) influx and voltage-dependent $\mathrm{Ca}(2+)$ channel activity by beta-amyloid-(1-40) in rat cortical synaptosomes and cultured cortical neurons. Modulation by the proinflammatory cytokine interleukin-1beta. J Biol Chem 275:47134718.

McGahon BM, Murray CA, Horrobin DF, Lynch MA. 1999. Age-related changes in oxidative mechanisms and LTP are reversed by dietary manipulation. Neurobiol Aging 20: 643-653.

Minghetti L. 2005. Role of inflammation in neurodegenerative diseases. Curr Opin Neurol 18:315-321.

Nolan Y, Vereker E, Lynch AM, Lynch MA. 2003. Evidence that lipopolysaccharideinduced cell death is mediated by accumulation of reactive oxygen species and activation of p38 in rat cortex and hippocampus. Exp Neurol 184:794-804. 
Table 1: Typical Mineral Composition of Aquamin.

\begin{tabular}{|c|c|}
\hline Mineral & Dry Salt Weight \\
\hline Calcium & $141,200 \mathrm{ppm}$ \\
\hline Magnesium & $18,580 \mathrm{ppm}$ \\
\hline Phosphorous & $436 \mathrm{ppm}$ \\
\hline Potassium & $81.5 \mathrm{ppm}$ \\
\hline Sulphur & $3620 \mathrm{ppm}$ \\
\hline Iron & $234 \mathrm{ppm}$ \\
\hline Boron & $8.45 \mathrm{ppm}$ \\
\hline Sodium & $1780 \mathrm{ppm}$ \\
\hline Manganese & $9.71 \mathrm{ppm}$ \\
\hline Cobalt & $<0.05 \mathrm{ppm}$ \\
\hline Copper & $0.191 \mathrm{ppm}$ \\
\hline Zinc & $10.7 \mathrm{ppm}$ \\
\hline Selenium & $1.75 \mathrm{ppm}$ \\
\hline
\end{tabular}




\section{Figure Legends:}

Figure 1: Aquamin prevents LPS-induced release of TNF $\alpha$ and IL-1 $\beta$. TNF $\alpha(\mathrm{A})$ and IL-1 $\beta$ (B) levels from LPS-stimulated glial-enriched cortical cultures. Data are expressed means \pm SEM of seven independent experiments, each performed in triplicate. $* * * \mathrm{p}<0.001$ vs. control; $++\mathrm{p}<0.01 ;+++\mathrm{p}<0.001$ vs. LPS (ANOVA). 

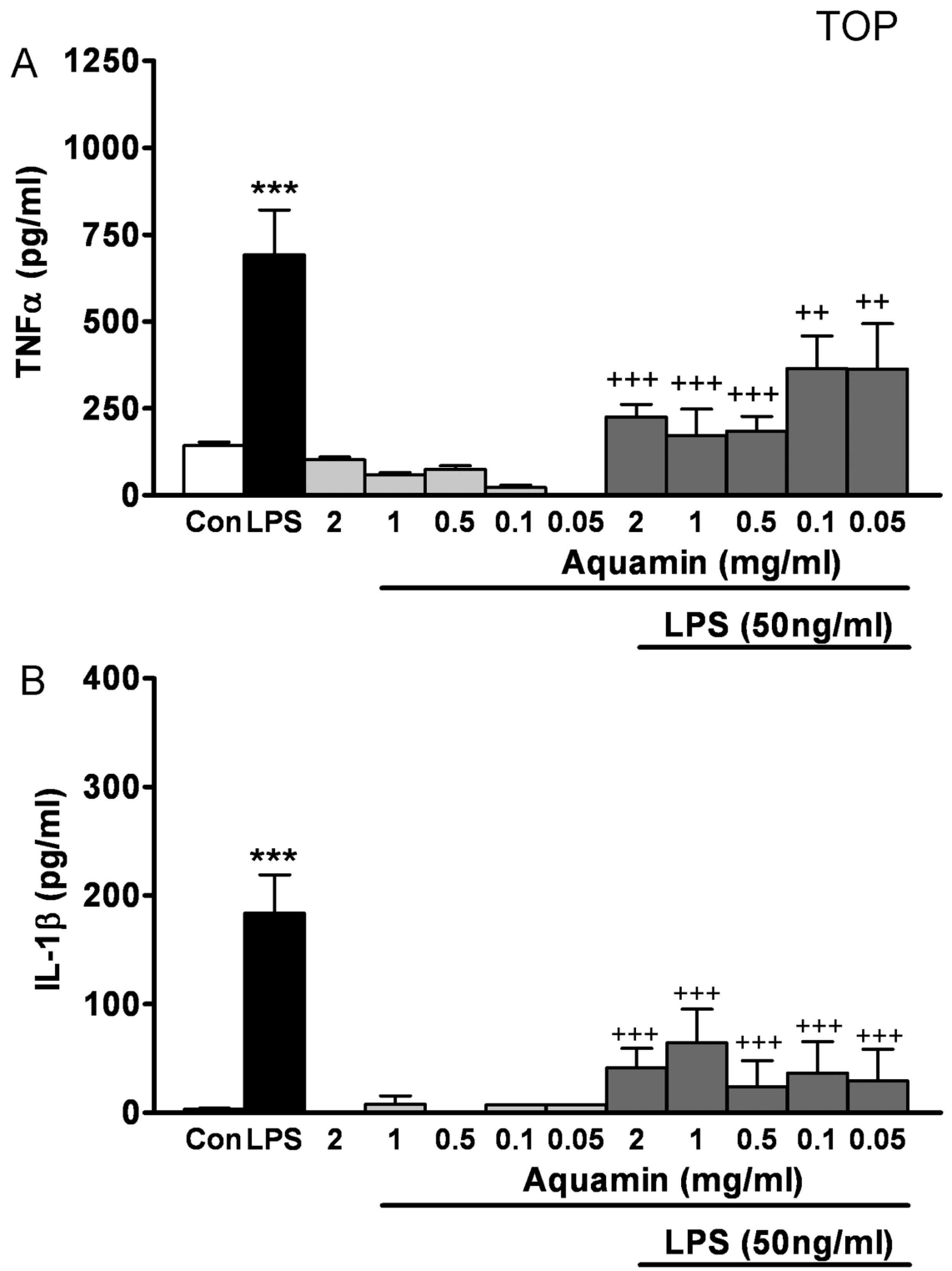

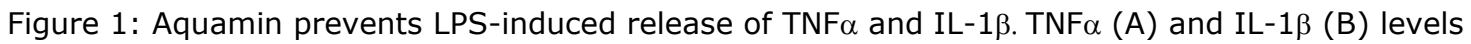
from LPS-stimulated glial-enriched cortical cultures. Data are expressed means \pm SEM of seven independent experiments, each performed in triplicate. $* * * p<0.001$ vs. control; $++p<0.01$; $+++p<0.001$ vs. LPS (ANOVA). $109 \times 141 \mathrm{~mm}(600 \times 600 \mathrm{DPI})$ 